\title{
現代建築作品におけるパブリックスペースとしてのロッジア的空間の性格 CHARACTERISTICS OF LOGGIA SPACE AS PUBLIC SPACE IN CONTEMPORARY ARCHITECTURE
}

\author{
金野千 恵*，宮城島 崇人**，塚 本由晴*** \\ Chie KONNO, Takahito MIYAGISHIMA and Yoshiharu TSUKAMOTO
}

\begin{abstract}
The aim of this study is to clarify the particular spatial characteristics of Loggia space, as public space, in contemporary architecture. Loggia space is defined as an ambiguity of architectural territory and at the same time an exterior space. Initially, the relationship between loggia space and interior space, such as positional relation of plan, section and supporting systems, is investigated. Secondly, the relationship between loggia space and adjacent external space, such as public squares, streets, and surrounding buildings, is investigated. Thirdly, the various typological characteristic of loggia space is generated through the combination of the building patterns and the adjacent external space patterns. Finally, the combination of two contrasting axis of spatial qualties, the architectural aspect of structure vs. covering and the external relation to openness vs. gap space, is clarified as a basic characteristic of loggia space.
\end{abstract}

Keywords : Loggia Space, Contemporary architecture, Public Space, Typology, Spatial Characteristic ロッジア的空間，現代建築，パブリックスペース，類型，空間の性格

\section{1. 序}

\section{1 研究の背景と目的}

建築における廊や庇空間といった「ロッジア的空間」注1, 注2) は、 各地の気候や習慣といった多彩な用件のなかで成立してきた、地域 や時代の違いを超えた普遍性のある空間といえる。また、その内部 が外部化したとも、外部が内部化したともいえる曖昧な性格は、様々 な用途やスケールに応用可能であり、これまで多くの建築家、建築 理論家によって様々なかたちで論じられてきた。A・パラーディオは、 ルネサンス後期以降、古典建築の文法に立脚した建築論のなかで、「建 物の有用さ」注3) に関する最も重要な要素の一つとしてロッジアを挙 げ、個人住宅注4) におけるファサードを美しく構成する歓待空間、あ るいは、風雨や強い陽射しを防ぐ公共建造物注5)における開かれた空 間として位置づけている。また、1960 年代以降、近代主義建築の見 直しを図る動きのなかで、伝統的な集落や都市空間に人間性の回復

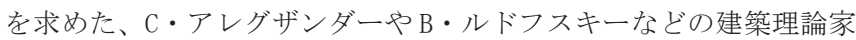
は、ロッジア的空間に、生活の喜びや地域固有の風土や文化と強く 結びついた建築の普遍的な価值を見出している注6, 注7)。いずれも、ロッ ジア的な空間を通して、都市空間や周囲の自然環境などを包括した より大きな秩序の中に建築が位置づけ直されることが意図されてい るといえる。
筆者らがこれまで行ってきたロッジア的空間に関する研究注8) とし ては、ロッジアやヴェランダ、テラスといった住宅作品にみられる プライベートな半屋外空間を対象に、ロッジア内での日照の時刻変 化や、隣接する室内での生活のふるまいとの関係を検討し、その構 成的な性格について報告したものがある。本稿では、都市の街路や 広場に接続することで、不特定多数の人の出入りが自由なパブリッ クスペースとしてのロッジア的空間の性格を明らかにするために、 公共建築に付随した屋根付き半屋外空間を対象とした検討を行う。

そうしたパブリックスペースの一部となるロッジア的空間の系譜 を代表するものとしては、イタリア、フィレンツェのシニョーリア 広場にある『Loggia dei Lanzi』がある。これは、14 世紀の共和国 体制において公式の儀式や祭礼を執り行うための広場の設えとして 建設されたルネサンス様式の建築で注9)、現在は広場に連続した彫刻 ギャラリーとして市民や観光客にも親しまれている。このようにロッ ジア的な空間は、現代社会においてもパブリックスペースの一つの 卓越した形式であり続けているが、ルネサンスの時代のような建築 様式がない現代建築作品では多様な構成形式が試みられている。そ うした構成形式の広がりの中に、現代におけるロッジア的空間の展 開を見出し、その構造の一端を明らかにすることが、本研究の目的 である。
* 東京工業大学大学院理工学研究科建築学専攻 博士課程・修士(工学)

** 東京工業大学大学院理工学研究科建築学専攻 修士課程・学士 (工学)

*** 東京工業大学大学院理工学研究科建築学専攻 准教授・博士 (工学
Graduate Student, Graduate School of Dept. of Architecture and Built Eng., Tokyo Institute of Technology, M. Eng.

Graduate Student, Graduate School of Dept. of Architecture and Built Eng., Tokyo Institute of Technology. B. Eng.

Assoc. Prof., Dept. of Architecture and Built Eng., Tokyo Institute of Technology, Dr. Eng. 


\section{2 研究方法と概要}

先に述べたように、現代建築におけるパブリックスペースとして のロッジア的空間の性格を、構成の検討を通して明らかにするため、 本研究では、公共施設を題材とした現代建築作品を対象に分析を行 う。研究資料は、評価が確立している国際的な建築ジャーナリズム 5 誌に掲載された、ロッジア的空間をもつ公共施設のうち、平面図、 断面図、写真などで空間構成が把握でき、周辺環境を含む立地を特 定できる注 10) 94 作品注 11) を対象とする。一つの作品中で複数の異 なる種類のロッジア的空間がみられる場合、それらを区別して、合 計９８のロッジア的空間を抽出した。また、資料は1971年まで遡っ て収集を行っているが注 12)、その 7 割以上が 1990 年代以降の作品で あることからも、ロッジア的空間の有効性が近年再評価されている ことが伺える（表 1 )。

本研究におけるロッジア的空間は、建物の一部で屋根がかかり、 柱などで画定されていながら、壁がないので外気が浸透した外部空 間でもある。そこで本稿では、〈建物〉がロッジア的空間と内部空間 からなり、〈外部空間〉がロッジア的空間とそこへ隣接する外部空間 からなるとする。これにより、〈建物〉と〈外部空間〉の干渉する空 間として、建物でありながら外部空間であるロッジア的空間の両義 ジア的空間の構成を、建物からみた構成と、都市の外部空間からみ た構成の両側面から検討する。まず、建物からみた構成として、建 物の内部空間（以下、内部空間）との平面、断面の関係、ならびに 支持形式を検討することで《建物パタン》を導き、加えて屋根架構 の特徵である屋根の絶対高さと奥行き、透過性、さらに外部地面に 対する床面について検討する注 ${ }^{13)}$ 。つぎに都市の外部空間からみた 構成を、各資料の建物が建てられた場所における隣接要素の種類と その配置から検討し《外部空間パタン》を導く。その上で、《建物パ タン》と《外部空間パタン》の重㸚合わせによって、パブリックスペー スとしてのロッジア的空間の構成類型を抽出し注 14 、それらがどのよ うな性格をもつのかを、相対的に明らかにしていく。 的な性格を定義している（表 2)。この両義性を捉えるために、ロッ

\section{3 既往研究及び本研究の意義}

ロッジア的空間のような半屋外空間を題材とする既往研究には、 まず、建築としての分節が施された外部空間をもつ建築作品を対象 とした坂本らの研究があり、現代住宅作品を対象に床、壁、天井と いった建築要素の組合せで定義される半屋外空間の構成類型と、そ れを成立させる内外の対比について論じるもの注 15$)$ 、現代建築作品 を対象に配置と建築構成によって捉えられる外部空間の構成類型と、 そこにみられる公私の対比を論じるもの注 16) などがある。次に、特 定の空間形式を扱ったものとして、辻原らによるアーケードを対象 とする研究がある。これには限定した地域にみられるアーケードの 形態と素材の歴史的な変遷に関する体系的な位置づけを行うもの注17、 注 18)、アーケードの日本における実践例が依拠する共同体と運営方法 について論じたもの注 ${ }^{19)}$ 、世界各地にみられるアーケード空間におけ る温熱環境の有効性について論じたもの注20) がある。また、峰岸ら による回廊を対象とする研究として、神社建築における回廊の形状 と信仰との結びつきについて論じたもの注 21$) 、$ 参道との関係から、神 社回廊の空間的性格を位置づけるもの注 22) がある。さらに、赤松に よる「ロッジア」と「リンギエラ」という 2 つの建築要素を対象と する研究注 23) においては、建設の目的と経緯、その後の使用法や形 態の変化から、それらを歴史的に位置づけている。

これらに対し、本研究は、現代建築作品におけるパブリックスペー スとしてのロッジア的空間を、建物からみた構成と、隣接する街路 や広場といった外部空間からみた構成の重ね合わせとして類型化す ることで、その性格を明らかにするものである。

\section{2. 建物からみたロッジア的空間の構成}

\section{1 建物の内部空間との関係と支持形式}

分析例（図 1）のロッジア的空間は、列柱によって支持された建 物高さよりも少し低い庇が、地面と建物の床面の高さを調整する幅 広の階段を伴って建物の間口全体に柱廊として配されたものである。 このように、建物の内部空間とロッジア的空間との関係を、平面、

表 3 建物の内部空間との平面の関係
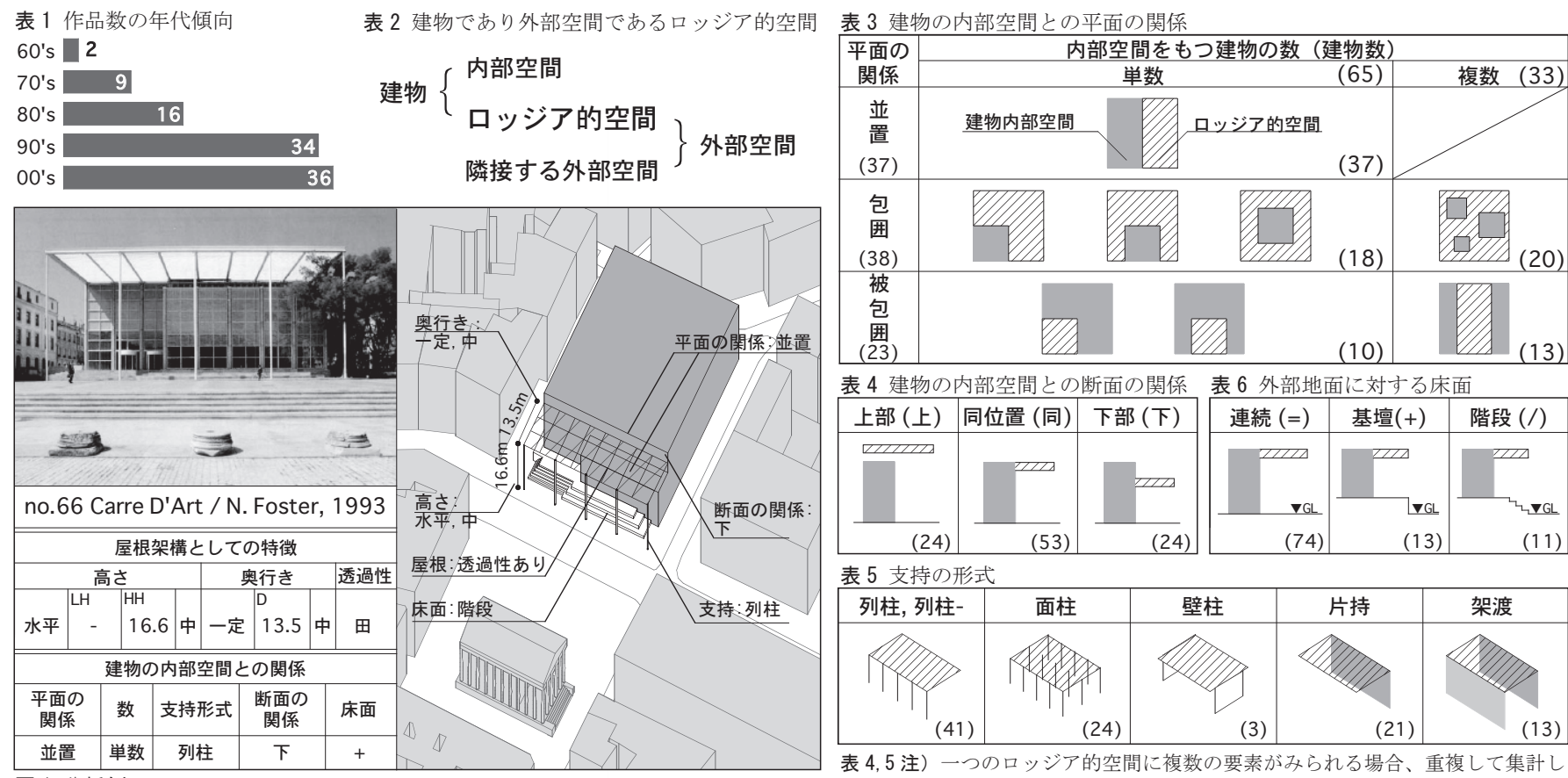

表 4, 5 注）一つのロッジア的空間に複数の要素がみられる場合、重複して集計し ているため、合計数は 98 以上となる。 
断面の関係、支持形式、および床面の高さから捉えることとする。

まず内部空間との平面の関係として（表 3)、ロッジア的空間が内 部空間を囲う〈包囲〉が最も多く、次いで、内部空間が並べられる 〈並置〉、内部空間に囲われる〈被包囲〉の順に多くみられた。また、 内部空間を持つ建物の数（以下、建物数）について整理すると、ロッ ジア的空間が複数の内部空間を囲う〈包囲・複数〉が、一つの内部 空間を囲う〈包囲・単数〉よりも多くみられ、ロッジア的空間が内 部空間の建物によって囲われる〈被包囲・複数〉が、一つの内部空 間によって囲われる〈被包囲・単数〉よりも多くみられた。つぎに、 内部空間との断面の関係としては（表 4)、ロッジア的空間の屋根を 建物屋根と同位置に設けるもの〈同位置〉が最も多く、下屋のよう に取り付くもの〈下部〉、内部空間の上部に浮遊させるもの〈上部〉 が同程度みられた。さらに、ロッジア的空間の屋根の支持形式とし ては（表 5)、柱が列状に配されファサードをつくる〈列柱〉、列状 の一部に柱が配され、列柱が間引かれたような〈列柱 -〉、複数の柱 が面的に反復して配される〈面柱〉、壁状の柱が配される〈壁柱〉、 建物から片持ちで固定支持されている〈片持〉、建物の桁どうしに架 け渡される〈架渡〉があり、列柱のものが全体の 4 割程度、面柱、 片持のものが全体の 2 割程度ずつみられた。最後に、外部地面に対 するロッジア的空間の床面は (表 6)、地面と高さを違えず連続的な ものが約 8 割みられたのに対し、基壇によってロッジア的空間の床 面が地面よりも高く設えられるもの、幅広の階段によって地面と建 物の床面を調整するものがそれぞれ約 1 割ずつみられた。

\section{2 ロッジア的空間の屋根架構}

次に、ロッジア的空間を覆う屋根架構の特徵として、屋根の絶対 高さと奥行き、屋根の透過性の有無を検討する。屋根の軒先の絶対 高さは、 $11 \mathrm{~m}$ 付近と $19 \mathrm{~m}$ 付近において資料の数值が不連続となるため、 これらを境に $11 \mathrm{~m}$ 未満を〈低〉、19m 以上を〈高〉、11m 以上 $19 \mathrm{~m}$ 未満 を〈中〉とした。さらに、軒先の高さが変化する場合はその高さを 列記したところ (表 7)、高さを一定に保ち水平性を強調する〈水平〉 が全体の資料の約半数を占め、高さを変化させリズムを生む〈変化〉 は約 4 割、地面から分節なく軒が連続する〈隆起〉が 1 割程度みら れた。屋根の奥行きは、内部空間との平面の関係に留意して「屋根 架構の外端から建物内部空間までの距離」として検討し、一定のも の〈一定〉、規則的に変化するもの〈規則変化〉、不規則に変化する もの〈不規則変化〉として整理した（表 8）注24)。また、奥行きの絶 対值を整理すると、一定と規則変化の場合〈浅〉、〈中〉程度の奥行 きが多くみられるのに対し、不規則に変化する場合〈深〉い奥行き が多くみられた。さらに、屋根の透過性のあるものの中には、ガラ スなどの透明素材によって光が透過するもの、ルーバー類や開口を 設けることで、日射に加えて雨や風が透過するものがみられた(表 9$)$ 。

\section{表 7 屋根架構の高さ}

\begin{tabular}{|c|c|c|c|c|c|c|c|c|}
\hline \multicolumn{2}{|l|}{ 水平(47) } & \multicolumn{4}{|c|}{ 変化(40) } & \multicolumn{2}{|c|}{ 隆起(10) } & \multirow{5}{*}{$\begin{array}{l}\text { 表 } 7 \text { 注）軒高一定の } \\
\text { ものを低、中、高の } \\
\text { いずれかで示し、変 } \\
\text { 化する軒は、高さを } \\
\text { 列記している。また、 } \\
\text { 隆起する軒は、0 } \\
\text { 最高である軒の高さ }\end{array}$} \\
\hline 低( 0-11m) & 22 & 低-低 & 15 & 中-中 & 2 & 0-低 & 5 & \\
\hline 中(11-19m) & 17 & 低-中 & 12 & 中-高 & 7 & 0-中 & 0 & \\
\hline 高(19m- ) & 9 & 低-高 & 0 & 高-高 & 4 & & 5 & \\
\hline \multicolumn{8}{|c|}{ 表 9 屋根架構の透過性 } & \\
\hline 透過性なし & \multicolumn{7}{|c|}{ 透過性あり } & \\
\hline 不透明材(ロ) & & 材( $\square)$ & & -バー類( & & 開口(回 & (2) & $\begin{array}{l}\text { 表 } 9 \text { 注）複数の要素 } \\
\text { がみられる場合には } \\
\text { 両方を集計に含め、 } \\
\text { 合計数は } 98 \text { 以上とな } \\
\text { る。 }\end{array}$ \\
\hline
\end{tabular}

\section{3 ロッジア的空間と建物パタン}

前節の結果より、内部空間の平面、断面の関係と、建物数、支持 形式の特徵的な組合せを検討することで、建物からみたロッジア的 空間の構成を 10 の建物パタンに分類した（表 10）。各パタンの特 徵と、屋根架構の傾向について述べる。

まず、ロッジア的空間が一つの内部空間と並べて配される〈単数 並置〉を、その支持形式によって以下の如く分ける。

《列柱・単数並置》: 一つの内部空間に並置され、列柱によって支持 される。軒高が比較的低く、奥行きが浅い傾向があり、基壇によっ て地面よりも床面が高く設えられるものが多い。いわゆる柱廊注 25$)$ と呼ばれるもので、序に述べた『Loggia dei Lanzi』が代表例とし て挙げられる。

《片持・単数並置》: 一つの内部空間に並置され、建物から片持ちで 支持される。比較的高い軒高、浅い奥行きで、透過性のない傾向が 強く、全て床面が地面と連続するものである。いわゆるキャノピー 注26）とよばれるものがこれにあたる。

《面柱・単数並置》: 一つの内部空間に並置され、面的に反復する柱 によって支持される。低い軒高のものが多く、比較的奥行きが深い 傾向にある。

《壁柱・単数並置》: 一つの内部空間に並置され、壁柱によって支持 される。高い軒高、深い奥行きのある門型になるものが多い。

つぎに、ロッジア的空間が内部空間を囲う〈包囲〉は、屋根が建 物上部に浮遊するように設けられるものが約半数あったため、まず これを《上部・包囲》として区別し、その他を支持形式によって以 下の如くまとめた。

《上部・包囲》: 内部空間の周囲かつ上部に配され、面的に広がる柱 や建物からの片持ちで支持される。軒高が変化し、なかでも高い軒 高や地面から連続的に隆起する屋根が多く、深い奥行きのものが大 半を占める。

《列柱・包囲》: 内部空間の周囲に巡らされ、列柱によって支持される。 水平に保つ低い軒高、浅い奥行きのものが多く、過半が日射を透過 する。いわゆる回廊注 27) とよばれるものである。

《片持・包囲》: 内部空間の周囲に巡らされ、建物から片持ちで支持 される。奥行きの浅いものが多く、全て床面が地面と連続する。《片持・ 単数並置》と同様、いわゆるキャノピー注 26) とよばれるものといえる。 《面柱・包囲》: 内部空間の周囲に巡らされ、面的に反復する柱によっ て支持される。

さらに、ロッジア的空間が内部空間によって包囲される〈被包囲〉 は、建物数によって以下の如く分けられる。

《単数被包囲》：一つの内部空間によって包讲され、ロッジア的空間 が建物を切り欠くように配される。比較的軒高が高く、日射を透過

表 8 屋根架構の奥行き

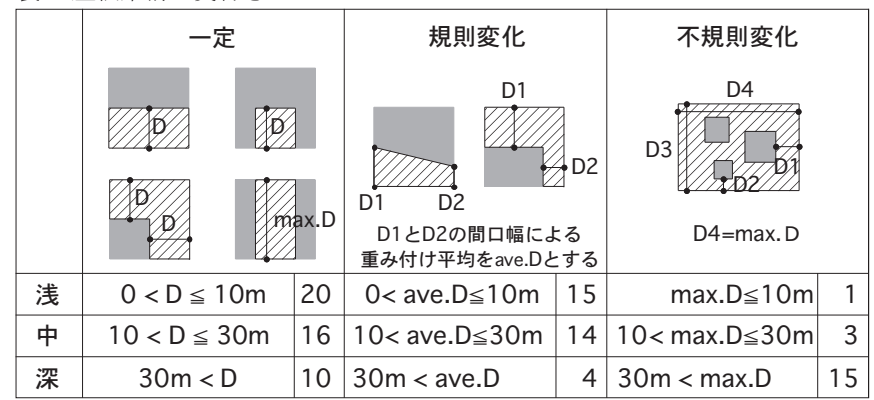


する傾向にあり、周囲より高い床面と地面との段差が階段によって 調整されるものが多くみられる。

《複数被包囲》: 複数の内部空間によって包囲される、すなわちロッ ジア的空間が複数の建物を繋ぐように配される。屋根架構が軒先の 高さを揃えて建物の桁に架け渡される〈架渡〉によって支持される ものが多く、非常に深い奥行きをもち、日射を透過する傾向にある。 ガレリア注 28)、またはアーケード注29) とよばれるもので、ミラノの 『Galleria Vittorio Emanuele II』が代表的な例として挙げられる。

このように、建物からみたロッジア的空間の構成は、建物のファ サードや列柱による構成的秩序と、外部空間の分節という二つの表 現のせめぎ合いとして捉えることができる。《列柱・単数並置》や《列 柱・包囲》は、明快な構築的秩序のある列柱、地面から高くなり切 り離された基壇、屋根架構の水平な軒など、ファサードとしての表 現が主調をなしつつ外部空間を引き込むものであるのに対し、《片持・ 単数並置》、《片持・包囲》、《上部・包囲》は、列柱や基壇といったファ サードを強調する建築要素を持たないことで、ロッジア的空間の覆 いとしての特徴がうまく引き出されるものである。また、《面柱・単 数並置》、《壁柱・単数並置》、《面柱・包囲》は、奥深くまで連続的 に地面を覆う屋根が、面的に反復する柱や壁柱による構築的秩序を 内蔵するのに対し、《単数被包囲》や《複数被包囲》は、その平面形 が建物壁面によってすでに確定されているので、そこに架け渡され た屋根架構の構築的秩序は相対的に弱くみることができる

さらに、これら建物パタンの年代傾向をみると、《列柱・単数並置》、 《面柱・単数並置》、《壁柱・単数並置》、《列柱・包囲》、《単数被包囲》、 《複数被包囲》は 1970 年代から 00 年代の今日に至るまで偏りなくみ られるのに対し、《片持・単数並置》、《上部・包囲》、《片持・包囲》、《面柱・ 包囲》は 90 年代以降のみにみられる。このことから、70、80 年代 においては、建物ファサードの主調をなすか、副次的な屋根架構か、 という構築的秩序の位置づけとしての表現が大半であったのに対し、 90 年代以降には、柱などの構築的な秩序を表現する要素を廃して、 より即物的に外部空間との連続を強調する表現も増加する傾向にあ るといえる。

また、ロッジア的空間の建物パタンには、《列柱・単数並置》を柱廊、 《列柱・包囲》を回廊、《片持・単数並置》、《片持・包囲》をキャノピー、 《複数被包囲》をガレリアまたはアーケードと呼ぶことができるよう に、建築言語として歴史的に名付けられているものがある。一方、《面 柱- 単数並置》、《壁柱- 単数並置》、《上部 - 包囲》、《面柱 - 包囲》、《単 数被包囲》といったパタンは、現代建築においては存在するけれども、 いまだ名付けられていないものである。

\section{3. 外部空間からみたロッジア的空間の構成}

ロッジア的空間は建物の一部であると同時に、外部の環境と連続 し街路や広場と隣り合うことでそれらと一体となってパブリックス ペースを形成している。たとえ建物として同じ形態のロッジア的空 間であっても、その都市空間への配され方によって、パブリックス ペースとしての性格は異なるものになるだろう。こうした性格を捉 えるために、この章では、ロッジア的空間と隣接する外部空間の構 成を検討していく。

\section{1 隣接する外部空間の要素}

分析例のロッジア的空間は (図 2)、周囲に対して 3 方向に開放し
表 10 ロッジア的空間の建物パタン

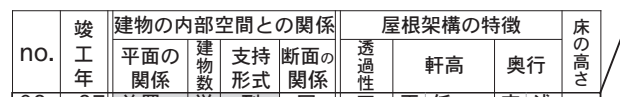
列柱 - 単数並置

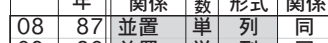
$09 a \quad 80$ 並置

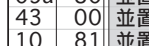
\begin{tabular}{ll|l|l|l}
10 & 81 & 並置 \\
37 & 05 & 並置 \\
\hline
\end{tabular} 49 99 並置

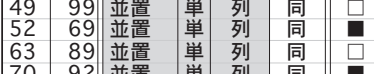
\begin{tabular}{ll|l|l}
73 & 92 & 並置 \\
\hline & 94 &
\end{tabular} \begin{tabular}{ll|l}
48 & 94 & 並是 \\
66 & 93 & 並置 \\
6 & 99
\end{tabular} \begin{tabular}{ll|l}
18 & 99 & 並置 \\
23 & 01 & 並 \\
\hline
\end{tabular}

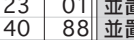
$09 \mathrm{~b} 80$ 並畺 \begin{tabular}{lr||}
46 & 94 \\
06 & p04
\end{tabular} \begin{tabular}{lr||r|}
06 & $p 04$ & 並置 \\
47 & 88 & 恶㯰 \\
7 & 94 &
\end{tabular} \begin{tabular}{ll|l}
74 & 94 & 並置 \\
58 & 72 & 並直
\end{tabular} \begin{tabular}{ll|l}
58 & 72 & 並置 \\
\hline 56 & 02 & 並直
\end{tabular} \begin{tabular}{ll|l|l}
41 & 95 & 並置 \\
3 & 02 &
\end{tabular} 38 02 普

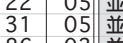
86 - 03 新置

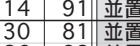

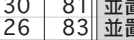

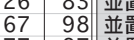

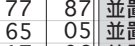

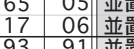
\begin{tabular}{ll||l|l}
93 & 91 & 並 \\
90 & 07 & 並置 \\
\hline
\end{tabular}

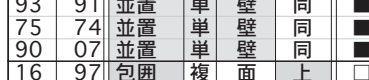

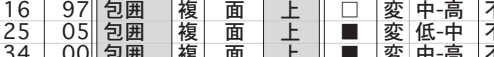

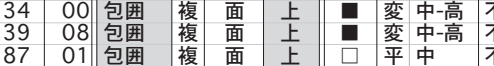
88 05 包田 9401 包国

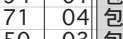
\begin{tabular}{ll|}
50 & 03 \\
57 & 03
\end{tabular} 笪

\begin{tabular}{ll|l|l|l|l}
20 & 05 & 包囲 & 複 & 片 & 上 \\
03 & 93 & 包囲 & 複 & 片 & 上 \\
\hline 片 & 上
\end{tabular}
$29 \mathrm{p} 06$ 包囲複片上 田変低-低不 33 00 包国

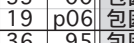
$05 b \quad 98$ 包国 15 92 包围 5184 包国

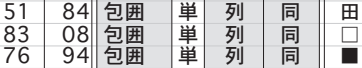

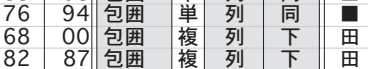
92 p07 包囲 24a 76 包国

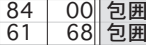

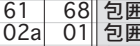

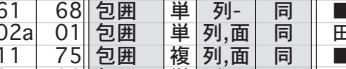

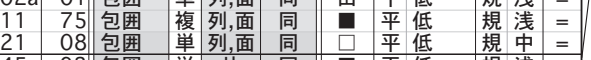

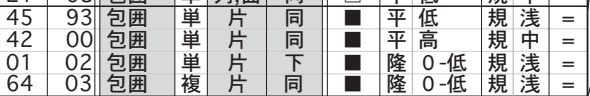

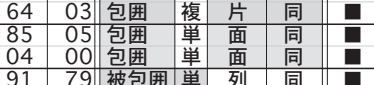

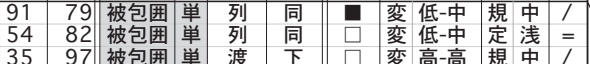

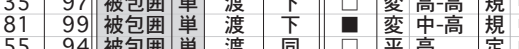

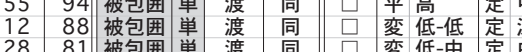

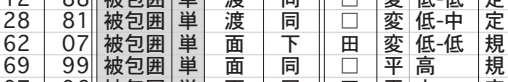

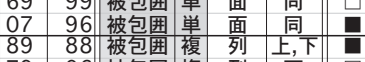

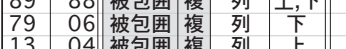

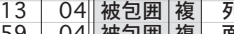
59 04 被包囲複 面 \begin{tabular}{ll|l|l|l|l}
78 & 85 & 被包囲複 & 面 & 上 \\
\hline 上
\end{tabular}

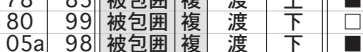
$24 \mathrm{~b} 77$ 被包囲複

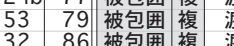
\begin{tabular}{rr|r|r|r|}
32 & 86 & 被包囲複 & 渡 \\
27 & 92 & 被包囲複 渡 \\
\hline
\end{tabular} $02 \mathrm{~b} 01$ 被包囲複渡, 面

表 10 注）表中の资料番号のうち、1つの建築作品に複数の口ッジア的空間がみられた場合 には、資料番号に続いて $\mathrm{a} 、 \mathrm{~b}$ 老付記して区別している。また、竣工年の「p」はプロジェ クトを表す。表中の記号は、表 $3 \sim 9$ に準じており、屋根架構の透過性、屋根の支持形式、 建物断面との位相関倸については、要素が複数みられた場合、それを列記している。 
ている。そのうち建物の間口を占める正面側は、街路を介して広場 に面し、残りの 2 方向は、一方が街路を介して建物に、他方が街路 を介さずに建物に面している。これらより、このロッジア的空間は、 敷地境界を越えた広場空間の連続の中に位置づけられているといえ る。このように、98のロッジア的空間に関し、隣接する外部空間 との関係を捉えるために、まず、ロッジア的空間の外部空間に対す る開放の面注 30 をを検討する。 3 面を開放するものが最も多くみられ、 次いで 2 面開放、 1 面開放、 4 面開放の順に多くみられた。これら を合計すると、2480開放面が全資料で確認できた。これら各々 の開放面について、接する街路の有無、敷地内要素として前広場の 有無、各種敷地外要素の有無を検討寸る(表11)。全ての開放面のうち、 街路と接するものが 8 割以上、敷地内要素として前広場をもつもの は 4 割程度で、その大半が街路に接することで前庭となる。敷地外 要素としては、建物が最も多く全体の約半数程度であり、既存広場 が 2 割程度、湖や森といった自然要素が 1 割程度であった。これら を組合せとして捉えると、敷地内に前広場を持たず街路に接し、そ の向かいに建物が面するもの（63）が最も多く、次いで前広場を介 して街路に接し、その向かいに建物が面するもの(39)注31)がみられる。 このことは、ロッジア的空間が街区の中で建物に隣接している場合 が多いことを示すといえる。また、既存広場や自然環境といったオー プンスペースに隣接する際の組合せの特徴としては、既存広場に隣 接する場合には、前庭をもたずに街路に接するものが多く、自然環 境に隣接する場合には、街路、前庭の有無に顕著な傾向はみられな かった。さらに、街路が直交する場合には、前広場をもたないもの が多かった。

\section{2 隣接する外部空間パタン}

前節で検討した、隣接要素によって特徴づけられた開放面の組合 せを、作品ごとのまとまりとして捉え、ロッジア的空間に隣接する 外部空間パタンとして 6 つに分類した（表 12）。まず、作品ごとに 隣接要素を整理すると、街路に接さずに配されるロッジア的空間は 3 資料にとどまることから、街路が接するか否かによる影響は少な いと判断し、ここでは主に敷地外要素の種類と前広場の有無によっ て外部空間パタンを分類することとする。

《建込み街路》: 敷地内外ともにオープンスペースをもたず、ロッジ ア的空間が街路に接する。部分的に街路幅を拡げるような特徴をも つものといえ、1 面、または 2 面接道のものが多くみられる。

《建込み街路前広場》：ロッジア的空間が街路を介して建物に面し、 敷地内に前広場を設ける。前広場がロッジア的空間とともに外部空 間のまとまりを形成し、敷地外においては建物などによって囲まれ るものである。

《既存広場》: 敷地内に前広場をもたずに、ロッジア的空間が既存広 場に面するもので、全パタン中もっとも多くみられた。ロッジア的 空間が既存広場による引きを伴って都市空間にあらわれ、既存広場 の領域を拡張しうるものである。2 3 資料中 5 資料と僅かではある が、街路を介さず既存広場に面するものもみられた。

《既存十前広場》: ロッジア的空間が、街路を介して既存広場と前広 場を併せ持ち、十分な引きがとれる。 3 面以上に開放するものが多 くみられた。

これら《既存広場》、《既存十前広場》は、運用によっては、接す る前面道路の広場化も可能にするものである。

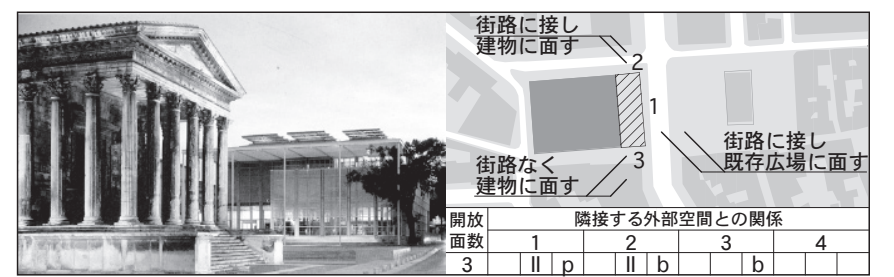

図 2 分析例

\begin{tabular}{|c|c|c|c|c|c|c|c|c|c|c|}
\hline 表 11 & \multirow{3}{*}{\begin{tabular}{l|} 
隣接寸 \\
敷地内
\end{tabular}} & \multicolumn{8}{|c|}{ 一外部空間の要素とその組 } & \multirow{5}{*}{$\begin{array}{l}\text { 表 } 11 \text { 注）表中において、 } \\
\text { - 既存広場には広場の他に } \\
\text { も公園や平面駐車場と } \\
\text { いった人の出入りの自由 } \\
\text { ) な開けた空き地を含む。 }\end{array}$} \\
\hline \multirow{4}{*}{$\begin{array}{c}\text { 接する } \\
\text { 街路 } \\
\text { (II) }\end{array}$} & & \multicolumn{8}{|c|}{ 敷地外要素 } & \\
\hline & & \multicolumn{3}{|c|}{ 既存広場自然環境既存広場| } & \multirow[t]{2}{*}{ 建物 } & \multirow{3}{*}{$\begin{array}{c}\text { ₹の他 } \\
\text { 婵地の庭 } \\
\text { 驾等 } \\
(-)\end{array}$} & \multicolumn{3}{|c|}{ 直交街路 } & \\
\hline & 前広場 & & & $\mid \begin{array}{c}+ \\
\text { 自然環境 }\end{array}$ & & & 広場 & & なし & \\
\hline & (f) & (p) & (n) & $(p, n)$ & (b) & & $(p=)$ & $(b=)$ & $\Leftrightarrow$ & \\
\hline 有 & 有 75 & 12 & 5 & 2 & 38 & 15 & 1 & 1 & 1 & また、その他には隣地の \\
\hline 204 & 無129 & 29 & $\frac{5}{7}$ & $\frac{2}{3}$ & $\frac{00}{63}$ & 19 & 3 & 0 & $\frac{1}{5}$ & 庭や、高架、並木、塀 \\
\hline 無 & 有 16 & 0 & 2 & 0 & 7 & 7 & 0 & 0 & 0 & いった人の出入りが自 \\
\hline 44 & 無 28 & 7 & 5 & 1 & 10 & 4 & 1 & 0 & 0 & でないものを含む。 \\
\hline
\end{tabular}

表 12 ロッジア的空間の外部空間パタン

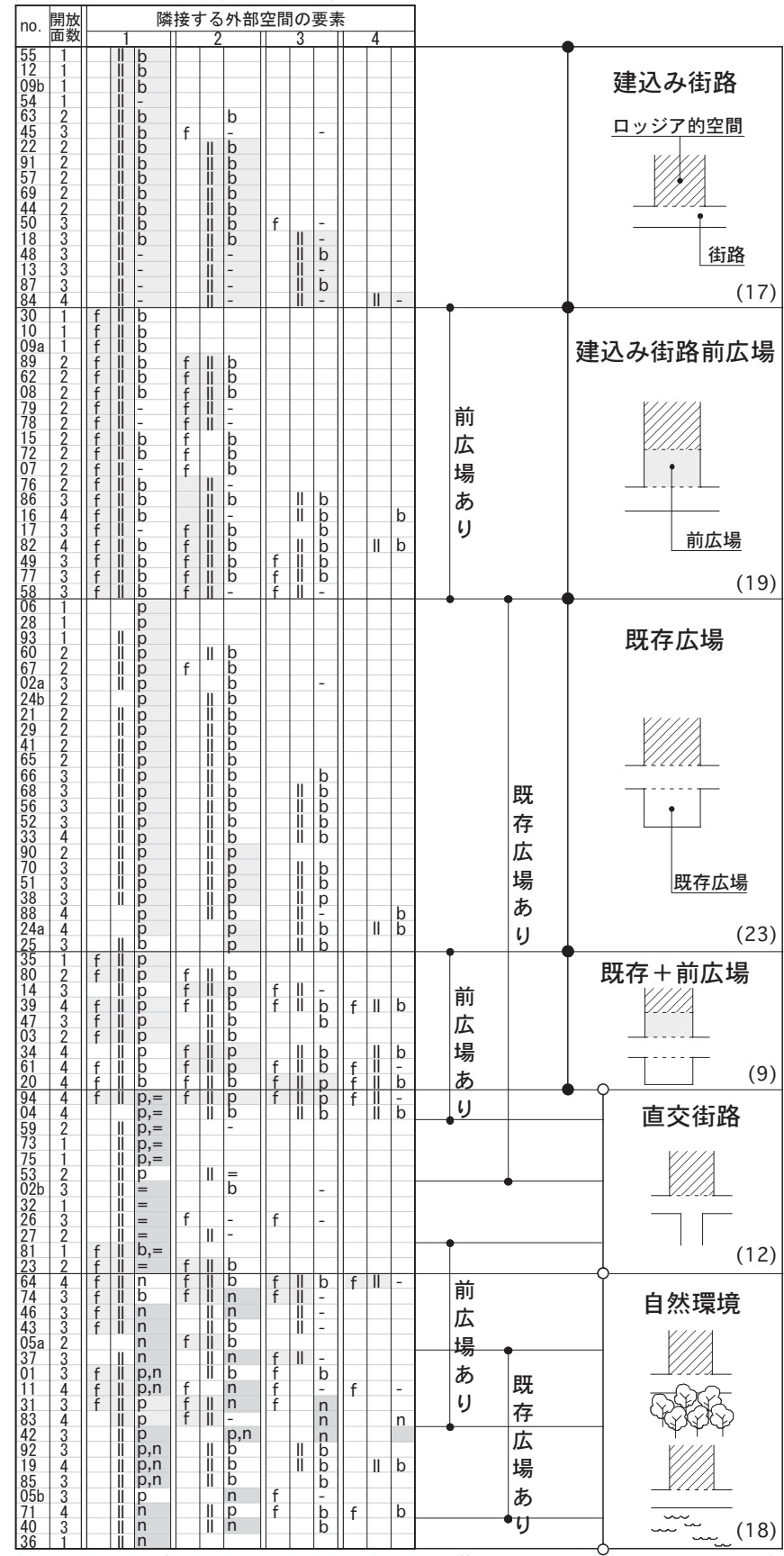

表 12 注）表中の資料番号のうち、1つの建築作品に複数のロッジア的空間がみられた場合 には、資料番号に続いて $\mathrm{a} 、 \mathrm{~b}$ を付記して区別している。表中の記号は表 11 に準じており、 開放面ごとに隣接寸る外部空閒の要素を、敷地内要素、街路、敷地外の対面要素の順に表 記し、対面する要素が複数ある場合それらを、パブリックスペースを有する面、隣接街路 の大きな幅員を有する面、建築的特徴の顕在化した面、という順序によって列記した。 
《直交街路》: ロッジア的空間の対面に街路が直交する。ロッジア的 空間が街路の延長の一部となるものといえる。1 面、または 2 面に 開放して、街路との連続を強調するものである。

《自然環境》: 河川や湖、森林からなる自然環境というオープンスペー スに隣接する。ロッジア的空間が街区などの境界を越えた広がりに 対するニッチのようになるものといえる。

これら《直交街路》、《自然環境》の 2 つのパタンは、既存広場や 前広場に隣接するものも含み、いずれのパタンも約半数が既存広場 に面し、《自然環境》では前広場に面するものも約半数みられた。
4 パブリックスペースとしてのロッジア的空間の構成類型とその性格

前章までは、ロッジア的空間の構成を捉えるにあたり、建物から みた構成（建物パタン）と、外部空間からみた構成（外部空間パタン） を個別に検討してきたが、本章では、この 2 つ重站合わせによっ てパブリックスペースとしてのロッジア的空間の構成類型を導くと ともに、類型を比較検討することで、その性格を明らかにする。 4.1 ロッジア的空間の構成類型

まず、建物からみたロッジア的空間の構成《建物パタン》を縦軸 に注32)、外部空間からみたロッジア的空間の構成《外部空間パタン》

表 13 ロッジア的空間の構成類型

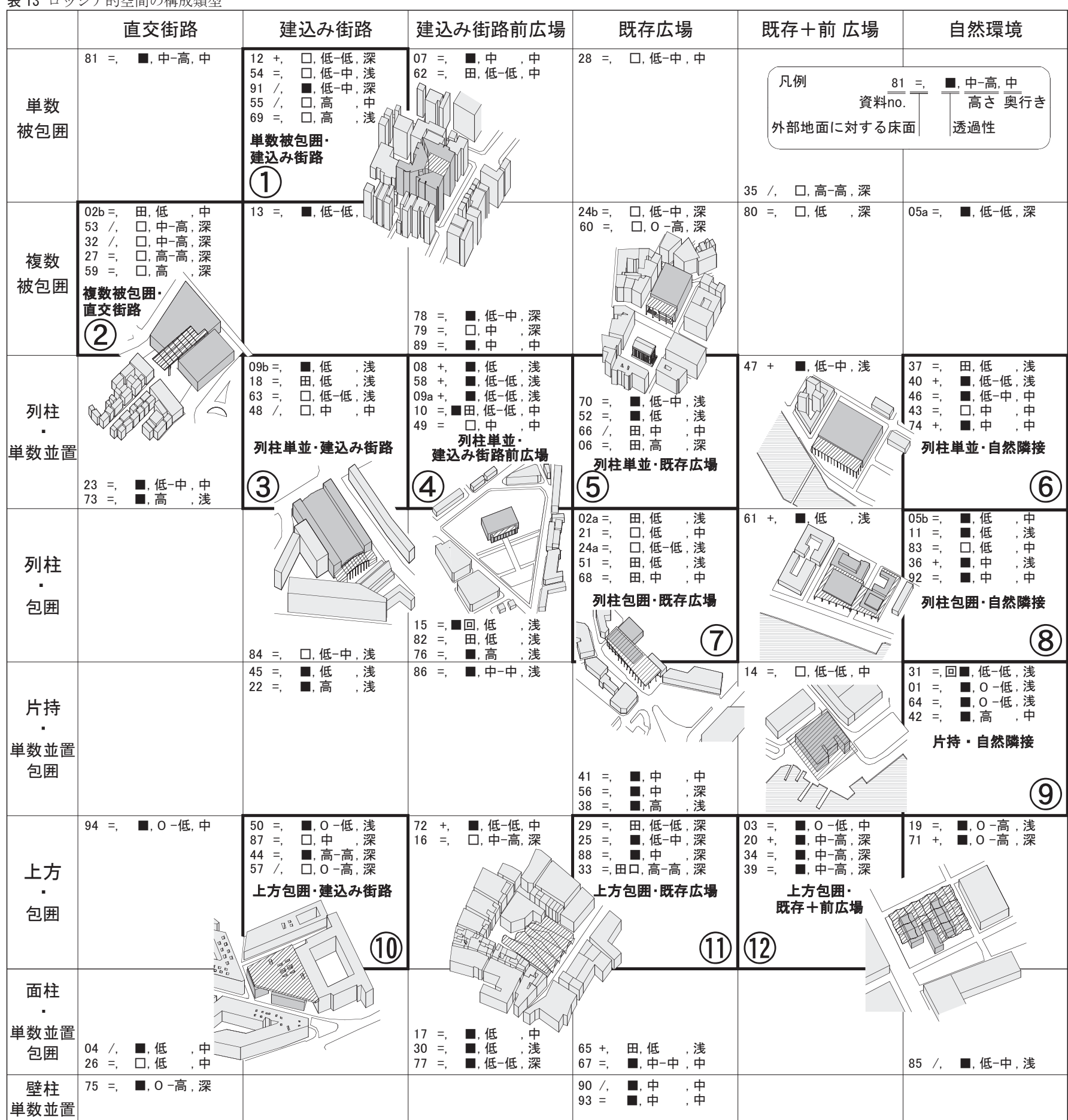

表 13 注）表中の記号は、表 $6 、 7 、 8 、 9$ に準じ、左から資料番号、外部地面に対する床面、屋根架構の透過性、高さ、奥行きをそれぞれ示している

表中の資料番号のうち、1つの建築作品に複数のロッジア的空間がみられた場合には、資料番号に続いて $\mathrm{a} 、 \mathrm{~b}$ を付記して区別している。

本文中の注 32）にあるように、建物パタンの「片持」と「面柱」は、性質が類似すること、資料数の少ないこと、により単数並置と包囲をまとめて扱うものとする。 
を横軸にマトリックスを作成し、全資料をプロットしたものが表 13 である。両パタンの組合せがとりうる可能性は、少なくとも $8 \times 6$ の 48 通り注33) に達するが、実際には特定の組合せに作品が集中す る傾向がみられたので、これらの組合せの一致が 4 資料以上にみら れるものを、ロッジア的空間の構成類型として抽出した。また、ロッ ジア的空間の屋根架構の特徵である、軒先の絶対高さ、奥行き、屋 根の透過性を作品番号と共に記し、その傾向を示した。以下、各類 型について説明する。

ロッジア的空間の平面形が各々の建物壁面によって確定され、屋 根架構が付加的に表現される〈単数被包囲〉、〈複数被包囲〉のうち、 《類型(1)》は内部空間を部分的に切り欠いたような屋根が、周囲の建 込んだ街路空間を部分的に呼び込むように配されるもので、日射を 透過して外部のような明るさをもつ傾向がある。《類型(2)》は日射を 透過する屋根が、複数の内部空間を繋ぎながら、直交する街路の延 長を引き込むように動線として連続させることで、都市空間との強 い連続性を示すもので、軒高が比較的高く、奥行きが深いものが多い。 また、《類型(1)、(2)》では、外部から奥へと導くような階段が床面に 設えられるものが多くみられた。

列柱を伴ってファサードが主調をなし外部を引き込む〈列柱・単 数並列〉、〈列柱・包囲〉のうち、〈列柱・単数並列〉パタンによるも のは《類型(3)- (6)》であり、《類型(3)》は街路を挟んで建物に面し、 建込んだ街路空間を部分的に呼び込むように屋根が配されるもので、 軒高が比較的低く、奥行きの浅い傾向がある。《類型(4)》は街路を介 して面寸る建物に囲われるなか、敷地内の前広場に面して屋根が配 されるもので、比較的軒高が低く、過半が基壇によってファサード を際だたせている。これらに対し、《類型(5)、(6)》は既存の都市空間 におけるオープンスペースに隣接してその拡がりの一部をなすもの で、《類型(5)はは街路を介して既存広場に面して屋根が配されること で、既存広場を取り囲むファサードの連続の中に奥行きのある間口 を挿入するもの、《類型(6)》は河川や湖、森林などの自然環境に向け て、ロッジア的空間が配されるものである。

〈列柱・包囲〉パタンによる《類型(7)、(8)》のうち、《類型(7)》は 既存広場を取り囲むファサードの一部として日射を透過する屋根が 配され、内部空間の周りヘパブリックスペースを連続的に引き込む
ものである。《類型(8)》は、類型(7) と同様の関係を自然環境に対して とることにより、例えば湖などを広場に見立てたように扱うもので、 すべて軒高を一定に保ち建物ファサードの水平性が強調されている。

ファサードとしての表現を弱め、覆いとしての特徴が強く引き出 される〈片持・単数並列, 包囲〉、〈上部・包囲〉パタンの《類型(9) - (12)》のうち、《類型(9)》は、建物から片持で伸びる奥行きの浅い屋 根が、自然環境に面して配されることで壮大なパノラマを施設のパ ブリックスペースに引き込むものである。軒高が変化し、日射を透 過せずに影を落とす傾向がある。内部空間の上部に屋根が浮遊する ように配される〈上部・包囲〉パタンの《類型(10) - (12)》のうち、《類 型(10)はは街路を挟んで建物に面し、建込んだ街路空間に広場をつく るように屋根が配されるもので、軒の地表面からの隆起や、高さの 変化が多くみられた。《類型11、(12)》は、いずれも既存広場に対し、 広場に匹敵する奥行きの深い空間が並置されたものである。《類型(11)》 は既存広場に面し、その領域を拡張寸るように屋根が配されるもの で、軒高の変化するものが比較的多くみられる。《類型(12)》は、既存 広場と前広場の双方に面し、広場とロッジア的空間の対比をみずか らの配置によっても強調するもので、日射を透過せずに影を落とし、 軒高は比較的高いといえる。

\section{2 パブリックスペースとしてのロッジア的空間の性格}

ここでは、建物との関係による性格と外部空間との関係による性 格が重ねられることにより導かれるロッジア的空間の性格の構造を 検討していく。まず、建物としてみた場合、列柱によって屋根架構 を支持することでロッジア的空間の構築的な秩序をファサードに表 出させる、すなわち《構築性を強調》するか、逆に構築的な秩序よ りは、屋根の覆いとしての特徵、すなわち《被覆性を強調》するか、 という性格の対比が成立している。つぎに、外部空間としての位置 づけをみた場合、建込む街路や直交街路の延長上といった、挟まれ た空間へとロッジア的空間が配される《狭間性への位置づけ》と、 広場や自然環境といった都市のオープンスペースーとロッジア的空 間が配される《開放性への位置づけ》という対比が成立している。 これらより、ロッジア的空間の、建物でありながら外部空間でもあ るという両義的な性格のなかに、建物としてみたときの《構築性》 と《被覆性》いずれの強調であるか、外部空間としてみたときの《狭

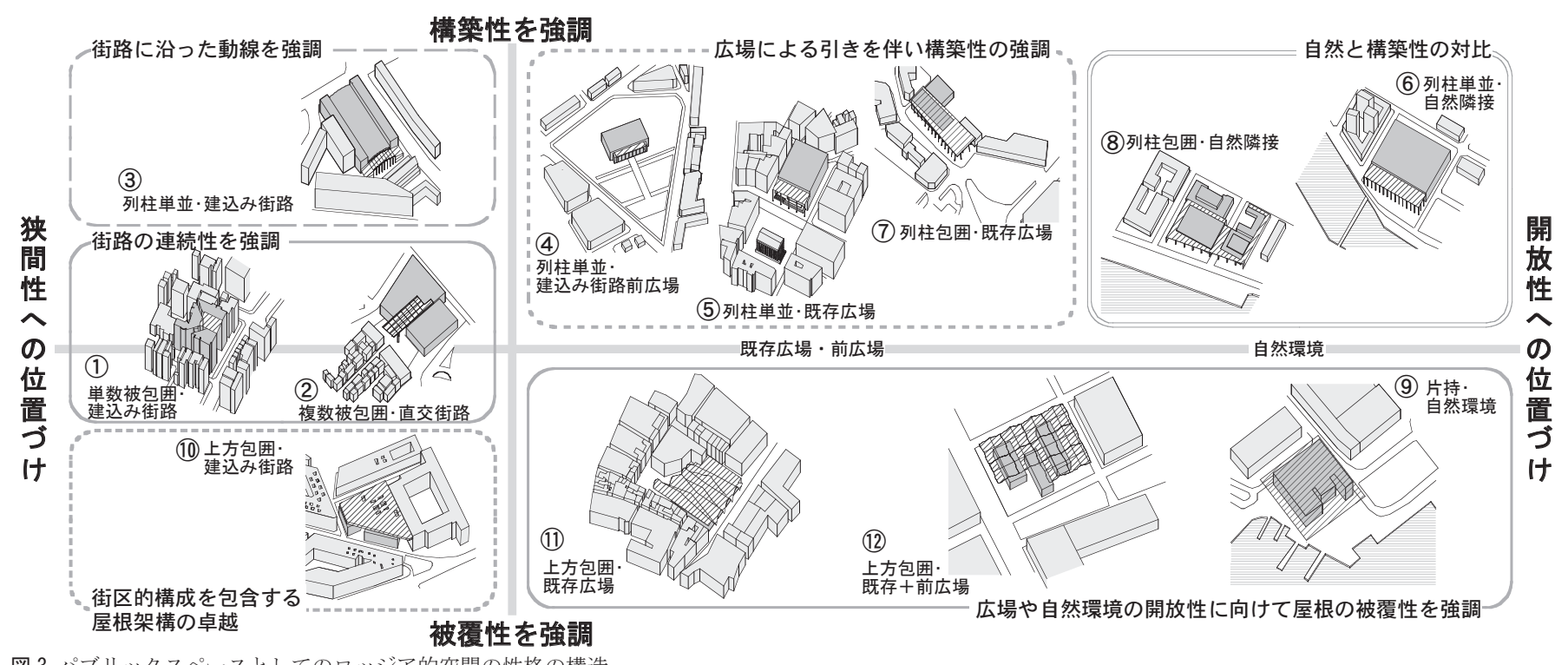


間性》と《開放性》いずれへの位置づけであるか、という 2 つ対 比軸を導くことができた。

そこで、前節で得られたロッジア的空間の構成類型を比較検討す ることで、この構造のなかでの類型間の相対的な関係づけを行う（図 3)。まず、被覆性を強調するロッジア的空間が開放性へと位置づけ られる類型9、(11)、12は、広場や自然といった都市のオープンスペー スに連続して、列柱または基壇を廃したロッジア的空間が、覆いを 強調するように配されるもの。構築性を強調するロッジア的空間が 開放性へと位置づけられるもののうち、類型(4)、(5)、（7)は、都市空 間に広場による引きを伴ってロッジア的空間があらわれ、列柱や基 壇などによるファサードの構築性が強調されるもの。さらに類型(6、 (8)は、ロッジア的空間が自然環境へと向けられることで、構築性が 自然との対比において強調されたものといえる。また、被覆性を強 調するロッジア的空間が狭間性へと位置づけられる類型11 は、都市 の街区と似たかたちで配置された建物部分を包含するように屋根架 構を浮遊させ、都市空間に対して卓越させる表現といえる。それに 対し、構築性を強調するロッジア的空間が狭間性へと位置づけられ る類型(3は、街路に沿った列柱により動線が強調されるものといえ る。さらに、建物壁面によって平面形の確定されたロッジア的空間 が狭間性へと位置づけられる類型(1)、(2)は、街路空間への連続性が 強調されたものといえる。

\section{5. 結}

以上、本研究では現代建築作品を対象として、パブリックスペー スとしてのロッジア的空間の性格の検討を行った。まず、付随する 建物の内部空間との平面、断面の関係、支持形式を組合せとして捉 え、建物パタンとして分類した。加えて、各々のロッジア的空間の 屋根架構の特徵を、軒高、奥行き、透過性から捉えた。さらに、隣 接する外部空間との関係を、接道、面する広場の種類、面する建物 の組合せとして捉え、外部空間パタンとして分類した。これら建物 パタン、外部空間パタンの重㸚合わせによりロッジア的空間の構成 類型を導き、その比較検討を行った。その結果、現代建築における、 建物でありながら外部空間でもあるというロッジア的空間の両義的 な性格は、建物としてみたときの《構築性》と《被覆性》の対比軸と、 外部空間としてみたときの《狭間性》と《開放性》の対比軸の重な りによって捉えられることを明らかにした。

\section{注}

注 1) イタリア語を語源とする建築の空間要素を表す言葉『Loggia（ロッジア )』は参考文献 1）のなかで、「14 世紀に使われ始めた建築要素で、屋根が柱 によって支えられた水平梁に載り、従来ポーチとして建物に付随して開放的 な構成をつくるものである。この構成は様々な用途をもち、中世の建築にお いては市民の集会空間として利用され、従来は教会の正面に開放された空間 として設けられていた。また、ルネサンス期には一般に私邸の歓待空間とし て設けられ、18 世紀からはそれが普及し最初にフランスへ、のちにヨーロ ッパの各国へと拡がった。と記されている。

注 2）ロッジア的空間とは、筆者らによる既往論文 (参考文献 2 における (注 7) ) において定義を行っているが、ここでは住宅に限定せずに様々な用途やスケ ールのロッジア的空間を含んでいる。

注 3）参考文献 3）のなかでは、“建物を有用にする 6 要素の一つ”としてロッ

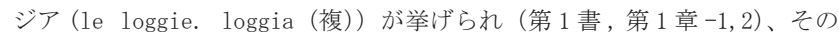
特徵を、「遊歩、食事、その他の気晴らしのためなど、多くの便益に役立つ。 また、建物の大きさと目的が要求するところに応じて、大きくも小さくもつ
くられる。と記されている（第 1 書, 第 21 章)。

注 4) 参考文献 3) のなかでは、個人住宅の建設に当たり留意す心゙き点として、「ロ ッジアと、広々とした装飾された広間」の必要性を挙げている（第 2 書, 第 1 章 $-1,2)$ 。

注 5）参考文献 3）のなかでは、「都市のなかの、真の『公共の』広場」に関す る記述として、「広場の周囲には列柱廊（i portichi）をめぐらす心゙きで、 その幅は円柱の高さと同じとする。列柱廊の効用は、雨、雪、および大気と 太陽がもたらすあらゆる重大な障害を避けることにある。」と記されている (第 3 書, 第 16 章 $-1,2$ )。

注 6） C. アレグザンダーの著書、参考文献 4）のなかでは、建設・計画におけ る具体的な実体を「パタン」として記述しており、ヴァナキュラーな建築か らの参照により「戸外室」，「一間バルコニー」といった比較的小さな、プ ライベートのスケールから、「公共戸外室」，「アーケード」，「外廊」，「生の 屋外空間」といった公共的なスケールまでの幅広いロッジア的空間に関する 記述を行っている。

注 7） B.ルドフスキーの著書、参考文献 5）のなかでは、地中海、アジアを中 心とした集落調查により発見されたロジアに関し「風土的建築に古くから つきものの設備であるロジアは屋根付の歩道から、多かれ少なかれ囲まれ た露台や歩廊を含み、列柱のあるホールまでの広い範囲にわたっている。」 p82-83 と記され、ロシア、コーカサス地方のアウル・シュレックやスペイ ン、マドリード郊外のチンチョンの家並みが例に挙げられている。また、参 考文献 6）のなかでは「キャノピーのある街路」「続・キャノピーのある街路」 として、イタリア、ボローニャのポルティコからなる街路空閒等を例に挙げ、 様々な時代や社会的背景において成立してきたポルティコについて記述して いる p70-100、p200-224。

注 8）参考文献 2)

注 9）参考文献 7) のなかでは、『Loggia dei lanzi(loggia della Signoria)』 に関し、その建設目的や経緯などを含む歴史的な文脈の記述がなされている。

注 10）各資料の周辺環境を含む立地については、雑誌に掲載された図面、写 真に加え、google earth を用いて位置の特定、詳細の分析を行っている。

注 11）本研究で選定された 94 資料の出典の内訳は（複数誌に掲載されたもの も全て含め、延べ数として表す)、

・『a+u』(1971 年 1 月号から 2008 年 12 月号まで) より 33 作品

・『domus』（1971 年 1 月号〈no. 494〉 から 2008 年 12 月号〈no. 920〉まで）よ り 21 作品

・『L' architecture D’ aujourd’ hui』(1971 年 1,2 月号〈no. 153〉から 2007 年 11, 12 月号〈no. 374〉まで）より 19 作品

・『Architectural Review』(1971 年 1 月号〈no. 887〉 から 2008 年 12 月号 〈no. 1342〉まで) より 34 作品

・『GA document』(no. 1 から no. 105 まで) より 35 作品

注 12）本研究において資料対象を 1971 年以降としている理由は、日本におけ る代表的な建築ジャーナリズムである『a+u 建築と都市』の創刊が 1971 年 であることが一つに挙げられるが、同時に、参考文献 8）の初版が 1966 年 に出版され、都市空間と建築単体との関係性が論じられるようになった時期 であることが挙げられる。

注 13）参考文献 3）のなかでは、広場にめぐらされるべき列柱廊の寸法体系 について、「広場の周囲につくられるすべての建物は、（アルベルティによれ ば、）広場の幅の $1 / 3$ より高くてはならず、1／6より低くてもいけない。 そして、列柱廊には階段で上ることとし、その階段の高さは、円柱の高さの $1 / 5$ とする」と記されている（第 3 書, 第 16 章 -2 )。このことから、古 典主義建築における形式としての列柱廊は、幅や高さといったスケールが重 要な表現要素の一つであったと考えられる。

注 14）ロッジア的空間の性格を「類型」として捉えているが、元来、「類型」 というものが都市形態との対応において反復され、繰り返されるものとして 位置づけられるのに対し、本研究では類型の概念を拡張し、ある特定の文脈 や特徴を共有する建築における表現の繰り返しに「類型」を見出すことで、 ロッジア的空間にみられる表現の広がりを捉えるものとする。

注 15）～注 22）は参考文献 9）～参考文献 16）に対応。

注 23）は参考文献 7）に対応。

注 24）ここで述べる屋根の奥行きは、建物の内部空間との関係によって捉え ているため、内部空間との平面の関係に留意する必要がある。屋根の奥行き が複数とれる場合は、これをD1、D2、D3 と記した。ロッジア的空間が単数 の内部空間と隣接する場合の奥行きは、一定または規則的な変化として捉え 
られる。この中で、奥行きが規則的に変化する場合、「奥行き $\times$ 間口の総和」 を「間口の和」で除した值を、奥行きの平均值〈ave. D として用いる。次 に、ロッジア的空間が複数の内部空間を包囲する場合は、多数の奥行きが生 じることから、最も深い奥行き〈max. D とついてのみ検討している。さら に、複数の内部空間によってロッジア的空間が包囲される（被包囲）の場合 は、屋根架構の外端から内部空間までの距離は一様に捉えられず、屋根架構 自体の最も深い奥行き〈max. D〉についてのみ検討している。

注 25）柱廊：柱を並心、梁をわたして屋根をかけ、吹き放しとした廊下。コ ロネード。(参考文献 17 )

注 26) キャノピー: 建築で天蓋形の庇, 屋根状の張出しテント。(参考文献 17) 注 27）回廊:元来は仏教建築や宮城の諸殿舎において、後に神社建築において、

聖域を構成するために空地の二方以上をめぐる細長い建物。梁行柱間は 1 間 または 2 間。一方の柱列を壁とする。(参考文献 18)

注 28）ガレリア：もともとは幅広の廊下、回廊の意味であるが、ガラス屋根

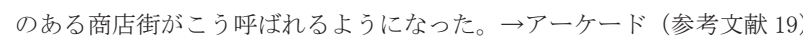

注 29）アーケード：4. 両側に商店が並んでいる道路に覆いを架けた商店街。 ↔ガレリア (参考文献 19)

注 30ここで「開放の面」とは、ロッジア的空間をな寸各面のうち、建物に隣 接する面、壁などによって塞がれた面を除いている。

注 31)ここで「前広場を介して街路に接し、その向かいに建物が面する」ものは、 〈接する街路十敷地内前広場 + 建物 (38) 〉 と、〈接する街路十敷地内前広場 十直交街路十建物（1）〉の和を示している。

注 32）建物パタンは 2 章において 10 パタン見出されたが、《片持・包囲》、《面 柱・包囲》はいずれも少数であり、これらを単数並置のものとまとめて、《片 持》、《面柱》として扱うこととした。

注 33) ここで「 $8 \times 6$ の 48 通りの組合せ」とは、建物パタンの 8 種類（列柱・ 単数並列、列柱 - 包囲、片持 - 単数並置, 包囲、面柱 - 単数並置, 包囲、上 部 - 包囲、壁柱 - 単数並置、単数被包囲、複数被包囲) と、外部空間パタン の 6 種類（建込夕街路、建込夕街路前広場、既存広場、既存十前広場、街路 延長、自然隣接）の組合せによるものである。

\section{参考文献}

1) ENCICLOPEDIA dell' ARCHITETTURA GARZANTI

2）金野千恵、塚本由晴:日照から見た住宅作品におけるロッジア的空間の性格,

日本建築学会計画系論文集，第 644 号, pp. 2289-2296, 2009. 10 .

3）A・パッラーディオ：建築四書，中央公論美術出版，初版伊語 1570

4) C・アレグザンダー : パタン・ランゲージ，鹿島出版会，1984

5）B・ルドフスキー: 建築家なしの建築, 鹿島出版会, 1986

6）B・ルドフスキー：人間のための街路，鹿島出版会，1973

7）赤松加寿江：15 世紀フィレンツェにおけるシニョーリア広場の儀式空間と しての機能, 日本建築学会計画系論文集, 第 590 号, pp. 187-194, 2005. 04.

8）A・ロッシ：L’architettura della citta(都市の建築), Padova, Marsilio Editori, 初版伊語 1966

9）塚本由晴、繁昌朗、坂本一成：現代日本の住宅作品における外部空間の分 節と統合，日本建築学会計画系論文集，第 470 号, pp. 95-104, 1995.4.

10）寺内美紀子、坂本一成、奥山信一: 建築の外部空間の分節と配置形式, 日 本建築学会計画系論文集, 第 491 号, pp. 91-98, 1997.1.

11）辻原万規彦、小林正美、中村泰人、外山義：西日本における都市の アーケードの成立および発展過程, 日本建築学会計画系論文集, 第 524 号, pp. 215-222, 1999. 10

12）辻原万規彦、藤岡里圭：東日本における都市のアーケードの成立と変容過 程，日本建築学会計画系論文集，第 584 号,pp. 51-58, 2004. 10.

13）辻原万規彦、藤岡里圭 : アーケードの原型としての日覆いに関する研究, 日本建築学会計画系論文集, 第 596 号, pp. 85-92, 2005. 10.

14）辻原万規彦、中村泰人、田中稳 : 都市の半戸外空間内部の温熱環境に関寸 る地理的差異を考慮した評価方法の提案, 日本建築学会計画系論文集, 第 519 号, pp. 101-108, 1999. 05

15）峰岸隆 : 神社建築における回廊の平面形と信仰形態について, 日本建築学 会計画系論文集，第 530 号, pp. 249-256, 2000.04.

16）峰岸隆：神社空間の参拝軸による回廊の造形的分析, 日本建築学会計画系 論文集，第 537 号, pp. 303-310, 2000. 11.

17）広辞苑, 岩波書店, 第四版, 1998

18）建筑大辞典, 彰国社, 1990

19）建築学用語辞典, 岩波書店, 第二編, 1999
付表 作品リスト

\begin{tabular}{|c|c|c|c|c|c|c|c|}
\hline & & & & 很の高さ & & & 星根の釆 \\
\hline no. & 作品名 & 建染家 & LH & HH ave.H & D1 & D2 & D3 \\
\hline & The Irish Hunger M & 1100 Archit & 0.8 & $\begin{array}{ll}7.0 & 3.9 \\
5 & .0\end{array}$ & $\begin{array}{r}7.3 \\
6.3\end{array}$ & 2.0 & \\
\hline & & $5+1$ associa & - & \begin{tabular}{l|l|}
5.0 & 5.0 \\
50 & 50
\end{tabular} & $\begin{array}{l}16.3 \\
24.8\end{array}$ & 3.8 & \\
\hline & & & $0 . \overline{0}$ & $\begin{array}{ll}3.0 & 5.0 \\
9.7 & 4.9\end{array}$ & 24.2 & 5.3 & \\
\hline & & & 0.0 & \begin{tabular}{|l|l|}
8.9 & 8.9 \\
\end{tabular} & 47.0 & 0.0 & \\
\hline $05 a$ & & & 6.8 & 7.6 & 49.3 & & \\
\hline $\begin{array}{l}05 b \\
06\end{array}$ & Portuguese & & - & \begin{tabular}{r|r|}
8.3 & 8.3 \\
\end{tabular} & 6.4 & 11.2 & \\
\hline $\begin{array}{l}06 \\
07\end{array}$ & $\begin{array}{l}\text { New exit for Uffizi } \\
\text { 岡山西警祭置 }\end{array}$ & $\begin{array}{l}\text { A. Iso } \\
\text { A. so }\end{array}$ & $\overline{-}$ & $\begin{array}{l}22.0 \\
16.022 .0 \\
16.0\end{array}$ & $\begin{array}{l}36.0 \\
21.2\end{array}$ & 43.0 & \\
\hline 08 & Pla's Platja Plaza & A. Masmique & - & & & & \\
\hline & 進修館 1 & Atelie & 4.1 & 6.6 & 3.8 & & \\
\hline & & Ateli & & 3.2 & 4.2 & 1.2 & \\
\hline & 名護市 & Atelier Z & 2.8 & 5.3 & 9.0 & 12.0 & \\
\hline & 今帰仁 & Atelier Zoo & & 3.5 & & 4.4 & 12.8 \\
\hline & Com & Aymonino, $\mathrm{P}$ & 7.3 & 8.5 & 58.6 & & \\
\hline & Rocinha I & Azevedo A. & 1.7 & \begin{tabular}{l|l|}
4.3 & 3.0 \\
7 &
\end{tabular} & 126.6 & 12.2 & 5.7 \\
\hline $\begin{array}{l}14 \\
15\end{array}$ & $\begin{array}{l}\text { Station Squre } \\
\text { Plenary Comp }\end{array}$ & $\begin{array}{l}\text { G. Behnisch } \\
\text { G. Behnisch }\end{array}$ & 2.8 & & $\begin{array}{l}8.6 \\
7.1\end{array}$ & 21.4 & \\
\hline 16 & & & 18.0 & & 85.5 & 14.6 & \\
\hline 17 & New Acropolis Must & B. Tschumi & - & \begin{tabular}{|l|l|}
9.5 & 9.5 \\
\end{tabular} & 25.0 & & \\
\hline 8 & & & - & \begin{tabular}{|l|l|}
3.0 & 3.0 \\
\end{tabular} & 4.2 & & \\
\hline 19 & Busan C & & & & & 504.0 & \\
\hline & $\begin{array}{l}\text { BMW V } \\
\text { BMakef }\end{array}$ & & $\mid 15.0$ & 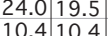 & $\begin{array}{l}78.6 \\
372\end{array}$ & 16.7 & $\begin{array}{r}40.5 \\
5.2\end{array}$ \\
\hline 22 & & & - & 22.9 & $\begin{aligned} 37.2 \\
6.5\end{aligned}$ & \begin{tabular}{|r|}
11.2 \\
$\mid 1.8$
\end{tabular} & \\
\hline & & & & & 14.4 & & \\
\hline & & & & & 2.0 & & \\
\hline & & & & & 42.0 & & \\
\hline & & & 5.3 & 9.7 & 91.6 & 3.5 & 6.5 \\
\hline & & & - & \begin{tabular}{rr|r|}
9.0 & 9.0 \\
5 & 9.0 & 0
\end{tabular} & & & \\
\hline 28 & $\begin{array}{l}\text { projec } \\
\text { Rhein }\end{array}$ & $\begin{array}{l}\text { F. } M c \text { c } \\
G, B c\end{array}$ & & $\begin{array}{l}50.045 .0 \\
11.5 \\
10.3\end{array}$ & 11.9 & & \\
\hline 29 & 5900 Wilshire Blvd. & $\begin{array}{l}\text { G. Bor } \\
\text { G. Lyr }\end{array}$ & 4.8 & \begin{tabular}{l|l|l|}
.0 .0 & 6.9 \\
\end{tabular} & 33.7 & 12.6 & \\
\hline & George R. Moscone & G. $\mathrm{Ob}$ & - & \begin{tabular}{ll|}
7.1 & 7.1
\end{tabular} & 9.6 & & \\
\hline & seum & H\&de & 8.3 & \begin{tabular}{c|c|}
10.0 & 9.2 \\
\end{tabular} & 9.4 & & \\
\hline & LACM & H. Pfeiffer A & 14.0 & 21.017 .5 & 41.7 & 34.7 & \\
\hline & Sony & H. Jahn & 40.0 & & 109.0 & 75.0 & \\
\hline & Expo & & 18.4 & 21.019 .7 & 80.6 & 30.0 & \\
\hline & & H. Ha & 23.0 & 46.834 .9 & 20.7 & 25.6 & \\
\hline & & & - & 11.811 .8 & 11.4 & 6.0 & 5.4 \\
\hline & & & - & 10.310 .3 & $\begin{array}{l}10.0 \\
7\end{array}$ & & \\
\hline & & & - & 20.020 .0 & $\begin{array}{r}7.6 \\
146 .\end{array}$ & & \\
\hline & & & 14.4 & 24.019 .2 & 146.4 & 60.0 & 15.0 \\
\hline & Perfo & & 7.6 & 10.0 & 5.4 & & \\
\hline 42 & & J. Nou & - & 14.0 & $\begin{array}{l}16.0 \\
30.5\end{array}$ & \begin{tabular}{|l|}
12.6 \\
25
\end{tabular} & \\
\hline 43 & & $\begin{array}{l}\text { J. Nol } \\
\text { J. Nol }\end{array}$ & $=$ & $\begin{array}{l}21.0 \\
12.2\end{array}$ & $\begin{array}{l}30.5 \\
24.3\end{array}$ & & 17.5 \\
\hline & & J. Nouvel & 34.0 & & 44.0 & 20.0 & \\
\hline & & & 70 & & 9.7 & 8.2 & 9.0 \\
\hline & & & 7.0 & & 10.6 & & \\
\hline & & & 10.5 & & $\begin{array}{l}10.0 \\
12.2\end{array}$ & & \\
\hline 49 & $\begin{array}{l}\text { Melun } \\
\text { Govert }\end{array}$ & $\begin{array}{l}\text { Jourda, Perri: } \\
\text { Jourda, Perri: }\end{array}$ & - & $\begin{array}{l}16.9 \\
15.5 \\
15.9 .5\end{array}$ & 12.2 & & \\
\hline & & J. Rubic & 0.0 & 8.0 & 8.3 & 2.5 & \\
\hline & & & - & 6.0 & 28.5 & 7.5 & \\
\hline & & & - & 6.5 & 7.2 & & \\
\hline & & & 15.0 & & 75.4 & & \\
\hline & & & 3.0 & & 7.9 & & \\
\hline & & & - & 35.035 .0 & 22.0 & & \\
\hline $\begin{array}{l}56 \\
57\end{array}$ & $\begin{array}{l}\text { Stadt } \\
\text { Feder }\end{array}$ & K. Ke & $0 \overline{0}$ & 18.2 & 31.0 & 05.3 & \\
\hline & & & 5.0 & & 3.5 & & \\
\hline 59 & & & & & 105.0 & & \\
\hline 60 & & & 0.0 & 6.8 & 515.0 & 24.0 & \\
\hline & & & & & 7.6 & & \\
\hline & & & 3.5 & & 42.1 & 7.4 & \\
\hline & & & 5.4 & & 9.8 & & \\
\hline & & & 0.0 & & 1.4 & 6.5 & 8.8 \\
\hline & & & & & 2.9 & 12.0 & \\
\hline & & & - & & 13.5 & & \\
\hline & & & 12.3 & & 45.0 & 18.8 & 0.0 \\
\hline & & & & & 6.4 & 7.5 & \\
\hline & & & - & & 16.8 & 4.5 & \\
\hline & & & 9.0 & & 9.9 & & \\
\hline & & & 0.0 & & 55.0 & 16.3 & 2. \\
\hline & & & 3.7 & & 11.9 & & \\
\hline & & & - & & & & \\
\hline & & & - & & & & \\
\hline & & & 0.0 & & 41.6 & & \\
\hline $87-2-2$ & & & $5 \overline{2}$ & 20.820 & $\begin{array}{r}9.0 \\
33\end{array}$ & 5.6 & \\
\hline & & & $\begin{array}{l}3.2 \\
7.0\end{array}$ & $\begin{array}{ll}0.1 & 1.0 \\
120 & 95\end{array}$ & 528 & & \\
\hline & & 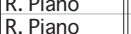 & 1.0 & & 01.8 & 94.0 & \\
\hline & & & - & & & & \\
\hline & & & 13.8 & & & 0.0 & \\
\hline & & & & & & 8.5 & 3.0 \\
\hline & & & & & & & \\
\hline & & & & & & & \\
\hline & & & .0 & & 26 & 2.9 & \\
\hline & & & 20 & & & & \\
\hline & Ham & & & & & & \\
\hline & & & & & & 25.5 & $8.1-1>3$ \\
\hline & & & & & & & \\
\hline & & & & & & & \\
\hline & & & 2.9 & & & & \\
\hline & & & - & & & 7.3 & \\
\hline & & & - & 16.416 .4 & 16.2 & 94 & \\
\hline & & & & & & & \\
\hline
\end{tabular}
付表注）表中において軒高は LH：最低高さ, HH：最高高さ, ave. H: 高さ平均として表す。 奥行きは、一定の奥行きをD1 のみで示し、変化する奥行きをD1, D2, D3 と記した。また、 内部空間との関係により ave. D : 平均奥行き、max. D : 最大奥行きを記した。 